УДК 316.344

DOI 10.18413/2712-746X-2020-44-2-259-270

\title{
Жизненные шансы в российской провинции
}

\author{
Реутов E.B., Реутова М.Н. \\ Белгородский государственный национальный исследовательский университет, \\ Россия, 308015, г. Белгород, ул. Победы, 85 \\ E-mail: reutovevg@mail.ru, reggina77@mail.ru
}

\begin{abstract}
Аннотация. Дифференциация географического, социального и культурного пространства России на «центр» и «провинцию» выражается в объективном и субъективном неравенстве возможностей достижения жизненных целей и успеха. Узость рынков труда, низкий уровень зарплат в большинстве отраслей региональных экономик, засилье непотизма и иных проявлений клановости консервируют традиционалистские ценности большей части жителей российской провинции, формируют неудовлетворенность социальной ситуацией и выталкивают наиболее амбициозных людей за пределы провинциальных социумов. Тем самым российское общество продолжает воспроизводить модель дифференцированного пространственного развития, а провинция остается преимущественно источником ресурсов для ограниченного количества точек роста и инноваций в стране.
\end{abstract}

Ключевые слова: провинция, пространственная дифференциация, жизненный успех.

Благодарности: работа подготовлена при финансовой поддержке РФФИ в рамках научного проекта № 18-011-00474 «Ментальные неравенства как фактор социальной поляризации российской провинции».

Для цитирования: Реутов Е.В., Реутова М.Н. 2020. Жизненные шансы в российской провинции. NOMOTHETIKA: Философия. Социология. Право. 45 (2): 259-270. DOI 10.18413/2712-746X-2020$44-2-259-270$

\section{Living chance in the russian province}

\author{
Evgenij V. Reutov, Marina N. Reutova \\ Belgorod National Research University, \\ 85 Pobeda St., Belgorod, 308015, Russia \\ E-mail: reutovevg@mail.ru, reggina77@mail.ru
}

\begin{abstract}
Life chances are considered as the probability of achieving life success, determined by the combination of external conditions (social, institutional, infrastructural) and the strength of the internal motivation of an individual or group. The differentiation of the geographical, social and cultural space of Russia into a «center» and a "province» is expressed, among others, in the objective and subjective inequality of opportunities to achieve life goals and success. The inequality of life chances is acutely recognized by the inhabitants of the Russian province in relation to the economic and cultural «centers» of the country, as well as within the provincial society - between villages and small towns, on the one hand, and regional centers, on the other. The narrowness of labor markets, the low level of salaries in most sectors of the regional economies, the dominance of nepotism and other manifestations of clanism preserve the traditionalist values of the majority of the inhabitants of the Russian province, form dissatisfaction with the social situation and push the most ambitious people beyond the boundaries of provincial societies. Thus, Russian society continues to reproduce the model of differentiated spatial development, and the province remains mainly a source of resources (labor, intellectual, etc.) for a limited number of growth points and innovations in the country.
\end{abstract}

Keywords: province, spatial differentiation, life chances, life success. 
Acknowledgements: The research was carried out with the financial support of the RFBR. Grant «Mental inequality as a factor of social polarization of Russian province» № 18-011-00474.

For citation: Reutov E.V., Reutova M.N. 2020. Living chance in the russian province. NOMOTHETIKA: Philosophy. Sociology. Law series. 45 (2): 259-270 (in Russian). DOI 10.18413/2712-746X-202044-2-259-270

\section{Введение}

Осмысление неоднородности социально-экономического, административнополитического и культурного пространства России, помимо иных аналитических концептов, включает измерение «центр - провинция». При всей его условности, использование в научном дискурсе такой модели пространственной и социокультурной дифференциации способствует лучшему пониманию разломов и неравенств российского общества, в основе которых лежат экономические, политические, природно-географические, демографические и социокультурные факторы. Имея первоначально политико-географический смысл (в буквальном переводе с латинского provincia - «подвластная территория»), понятие «провинция» стало рассматриваться в более широком культурологическом контексте: «рассматривая хронотоп русской провинции с учетом историко-философских, культурологических, социально-нравственных идей, рожденных в России последних (как минимум) полутора столетий, можно установить, что русская провинция предстает как явление специфическое, мало зависимое от географических координат, имеющее корни в душе человеческой не менее, чем в истории» [Злотникова и др., 2014, с. 129].

Провинциализм часто несет в себе негативные коннотации - как нечто несовершенное, уступающее по уровню развития центру, особенно в условиях жесткой политической централизации. В.Б. Звоновский отмечает, что «под влиянием внешних факторов и целенаправленных действий государства российская провинция долгое время оставалась неполной провинцией, социальной периферией, центр которой находился в столице государства - Москве» [Звоновский, 2003, с. 85]. Однако и современные практики политического управления России, несмотря на закрепленные в Конституции федерализм и де-юре независимое от государственной власти местное самоуправление, зачастую связаны с жестким контролем, а то и подавлением любых проявлений суверенитета локальных общностей. С.Г. Кордонский с соавторами отмечают аксиологическую и методологическую позицию политических элит, «при которой страна рассматривается как объект подражательного реформирования, а не как самобытная и в значительной степени самодостаточная реальность» [Кордонский и др., 2011, с. 5]. По итогам масштабной работы по составлению социокультурных портретов регионов России во второй половине 2000-х гг. Н.И. Лапиным отмечено следующее: «Достаточно высокий по своему уровню культурный потенциал регионов (то есть, по большому счету, провинции) лишь в небольшой своей части трансформируется в культурный капитал. Имеются социально-институциональные факторы, целые сферы деятельности, которые тормозят развитие регионов. В них сосредоточиваются и консервируются негативные характеристики, которые способствуют депрессивному состоянию всего региона» [Лапин, 2010, с. 33].

Под провинцией мы будем понимать совокупность территорий, находящихся на достаточном удалении от административно-политического и культурного центра (центров) государства, а также точек инновационного экономического роста и несущих на себе отпечаток зависимости и вторичности в воспроизводстве социальных практик и отношений.

Разделение России на центр и провинцию или Москву и регионы, а зачастую и противопоставление их друг другу присутствует и в массовом сознании россиян, большая часть которых - именно жители провинции. Острота такого противопоставления, возмож- 
но, несколько снизилась с 1990-х гг. - по причинам, связанным с ростом трудовой мобильности россиян, развитием новых макрорегиональных центров экономического роста (Санкт-Петербург, Краснодар), формированием, благодаря интернету, единого информационного пространства. Можно предположить, что в массовом сознании россиян неравномерность территориального развития и неоднородность социального пространства в настоящее время осознается уже не в терминологии системного конфликта, а в понятийном конструкте жизненных шансов - как с точки зрения их неравенства для жителей «центра» и «провинции», так и в отношении тех возможностей, которые мегаполисы предлагают всем амбициозным провинциалам.

Жизненные шансы в качестве комплекса условий для достижения индивидом желаемого статуса, но в большей мере фактора социальной дифференциации и классовой структуры рассматривал М. Вебер. Принадлежность к «классу» М. Вебер определял через «типичные шансы получения прибавочного продукта, внешние условия жизни и личный жизненный опыт, поскольку эти шансы детерминированы объемом и видом власти (либо недостатком таковой) распоряжаться товарами или квалификацией в целях получения дохода в рамках данного экономического порядка» [Вебер, 1994, с. 148].

Трактовка жизненных шансов М. Вебера получила дальнейшее развитие в рамках современной социологии. Концепцию жизненных шансов, встроенную в теорию конфликта, Р. Дарендорф начал развивать во второй половине 1970-х гг. [Dahrendorf, 1979] и систематизировал в 1990-х. О роли концепта «жизненных шансов» в осмыслении социального конфликта говорит его высказывание: «Конфликты современного общества связаны именно с жизненными шансами людей» [Дарендорф, 2002, с. 33]. Трактуя жизненные шансы как «нечто большее, чем предпосылки действия, и все же меньшее, чем фактические действия» [Дарендорф, 2002, с. 33], Р. Дарендорф указывал на виртуальный характер жизненных шансов, на тот потенциал для достижения жизненного успеха конкретным индивидом, который лишь заложен в комбинации институциональных и экономических условий, на значимость для реализации жизненных шансов той мотивации, которая формируется у индивида благодаря переплетению культурных ценностей и субъективного целеполагания: «Когда речь зайдет о цели повышения и увеличения человеческих опций, мы будем говорить просто о жизненных шансах... Это, однако, известное упрощение. Жизненные шансы лишь частью являются опциями; другая их часть связана с координатами, внутри которых опции обретают смысл... Вероятно, здесь можно говорить о некоей глубинной культуре, поддерживающей и направляющей людей» [Дарендорф, 2002, с. 35].

Э. Гидденс рассматривал жизненные шансы как «возможности, которыми индивид обладает при распределении социально созданных экономических или культурных благ, присутствующих обычно в любом обществе» [Giddens, 1973, с. 130]. Д. Эйцен и М. Зинн отмечают, что характерная особенность жизненных шансов состоит в том, что они описывают долгосрочную ситуацию в жизни, характеризуя шансы на «качественную жизнь» и «благоприятный опыт на протяжении всего жизненного пути» [Цит. по: Аникин, 2018, c. 46]. Р. Брин задавался вопросом, в какой степени такие вещи, как неравенство в жизненных шансах между индивидами и семьями, структурированы на основе класса и предлагал рассматривать имеющиеся у индивидов жизненные шансы в контексте доступа к редким и ценным благам [Breen, 2005]. В современном обществе, в котором доминирует индивидуализм и возникает, казалось бы, множество шансов, что можно охарактеризовать как «жизнь в мире, полном возможностей, каждая из которых более привлекательна, чем предыдущая» [Бауман, 2008, с. 70], далеко не каждый индивид может в полной мере реализовать эти шансы.

В современной отечественной социологии есть немало исследований, посвященных жизненным шансам представителей различных социальных групп применительно к тем или иным сферам общественной жизнедеятельности [Кузьмина, 2013; Пинская и др., 2014; Ильин, 2019; Каравай, 2019]. Представителями социологии при исследовании лич- 
ных планов учащейся молодежи отмечено существование «закономерных связей между факторами, определяющими социальные позиции молодежи (пол, местожительство, социальное происхождение), и их ориентациями и ожиданиями при подготовке в учебные заведения» [Чередниченко, 2005]. То есть речь идет фактически о том же самом наборе альтернативных жизненных траекторий, спектр которых шире, или уже в зависимости от ряда статусных позиций индивида.

Основываясь на существующих в научной литературе трактовках, можно определить жизненные шансы как задаваемую внешними условиями (социальными, институциональными, инфраструктурными) и силой внутренней мотивации индивида или группы вероятность достижения жизненного успеха.

Поскольку жизненные шансы - это, так или иначе, вероятность достижения жизненных целей, при их исследовании необходимо понимание того, какова иерархия жизненных целей в том или ином сообществе и что является критериями жизненного успеха. В российском обществе традиционализм и консерватизм не только обусловлены социокультурной матрицей, но и выполняют компенсационную функцию в условиях непредсказуемости изменений и невозможности большей части населения влиять на принятие политических решений. Соответственно, цели, ценности и установки людей в значительной мере связаны с воспроизводством привычных макро-, но главным образом, микросоциальных структур и процессов, которые, по крайней мере, предсказуемы и не обладают потенциалом внутренних и внешних конфликтов.

\section{Эмпирическая база и методы исследования}

Эмпирической базой статьи являются данные социологического исследования «Ментальные неравенства как фактор социальной поляризации российской провинции», проведенного в Белгородской и Воронежской областях в 2018-2019 гг. В качестве методов сбора информации выступали массовый анкетный опрос $(\mathrm{N}=1200$ респондентов) и интервьюирование ( $\mathrm{N}=50$ респондентов). Выборочная совокупность анкетного опроса формировалась на основе квотной выборки; параметрами квотирования выступали пол, возраст, поселенческий статус. Белгородская и Воронежская области были представлены равным количеством респондентов. Для отбора участников интервью использовалась стихийная выборка, но с обязательным представительством жителей крупных и малых городов, а также сел и поселков.

Выбор регионов исследования был обусловлен тем, что Белгородская и Воронежская области являются достаточно типичными территориями Российской Федерации. Так, показатели их экономического и демографического развития близки к общероссийским. При этом сами эти регионы отличаются друг от друга размером, численностью населения и в определенной степени уровнем провинциализма.

\section{Основные результаты}

При изучении жизненных шансов важно понимать конфигурацию локусов контроля в осознании индивидом возможностей влияния на собственную жизненную траекторию. Так, доминирование внешнего либо, наоборот, внутреннего локуса контроля способно ослабить или, соответственно, усилить действенность внешних по отношению к индивиду условий его самореализации. Чем сильнее выражен внутренний локус контроля, тем больше вероятность проявления индивидом активных адаптационных стратегий. Хотя, конечно, данная ситуация содержит в себе и риск фрустрации - например, в случае сильного диссонанса между явно выраженным внутренним локусом контроля и «барьерными» по отношению к вертикальной мобильности внешними обстоятельствами.

Согласно результатам исследования, ни внутренний, ни внешний локус контроля нельзя отнести к однозначно доминирующим в осмыслении факторов достижения жиз- 
ненного успеха. Так, для 60,3 \% опрошенных личные усилия и активность являются ключевым фактором достижения или недостижения богатства и успеха. На втором по значимости месте находится помощь со стороны ближайшего окружения индивида, особенности микрогрупповой социализации, выраженные в нашем исследовании параметром «семейное воспитание, помощь семьи и родственников». Его роль в достижении богатства и успеха отметили 40,2 \% опрошенных. На третьем месте - стечение обстоятельств, судьба $(22,8 \%)$, которые отражают не зависящие ни от индивида, ни от социума обстоятельства. Несправедливость общественного устройства - параметр, в наибольшей мере выражающий внешнюю локализацию жизненного успеха и социального неравенства, находится по своей значимости на четвертом месте (18,8 \%). Изначальное неравенство способностей, заложенное самой природой, отметили 15,2 \% опрошенных.

Следует отметить наличие четкой обратной связи возраста респондентов и субъективной роли личных усилий в достижении жизненного успеха. Если среди респондентов 60 лет и старше на значимость данного фактора указали 44,2 \% опрошенных, то среди представителей возрастной группы 40-59 лет - 55,7 \%, 30-39 лет - 63,7 \%, а среди молодежи 18-29 лет - 78,6 \%. При этом среди молодежи - и наиболее значительная доля тех, кто считает достижение или недостижение жизненного успеха производной от семейного воспитания и помощи семьи и родственников. То есть значительная часть респондентов, особенно молодежи, не усматривает никакого внутреннего противоречия в сочетании двух, казалось бы, различающихся по своему характеру факторах достижения жизненного успеха.

Таким образом, личная активность, хотя и оказалась во главе иерархии факторов достижения жизненного успеха, уступила совокупности всех остальных факторов, имеющих отношение уже к внешнему локусу контроля жизненной ситуации. Многие респонденты, ставящие в основу жизненного успеха личные усилия, считают их все же не вполне эффективными без благоприятствующих им внешних обстоятельств, основным из которых является социальный капитал семьи. Значимость семейно-родственных сетей как ведущего адаптационного ресурса домохозяйств и ресурса развития индивида в современном российском обществе доказано многочисленными исследованиями, в том числе проведенных авторами данной статьи [Реутов и др., 2019].

Основным критерием жизненного успеха для жителей российской провинции, как уже отмечалось авторами, является семейное счастье, субъективно значимое для 64,3\% опрошенных. На втором месте находится материальное благополучие (41,5 \%). Важно отметить, что и первый, и второй параметры жизненного успеха, по большому счету, характеризуют приватную сферу. Напротив, профессиональная самореализация, которая выходит за пределы приватности, в качестве критерия жизненного успеха декларируется лишь 26,5 \% опрошенных. Еще в меньшей мере достижительские стратегии, лежащие за пределами приватной сферы, связываются с карьерой, которая в качестве критерия жизненного успеха значима лишь для 13,8 \% респондентов (среди молодежи 18-29 лет - 21,0 \%). На полный отказ от какой-либо личной и социальной активности ориентированы 14,8 \% опрошенных - те, которые в качестве критерия жизненного успеха выбрали тихую, спокойную жизнь (чаще всего это респонденты 60 лет и старше - 24,9 \%). Малозначимыми критериями жизненного успеха являются признание, одобрение со стороны окружающих $(8,9$ \%) и яркие впечатления $(7,3 \%)$ [Реутов, Реутова, 2019, с. 416 ].

Институциональная структура жизненных шансов задается, прежде всего, институтами образования и рынка труда. Первый формирует профессионально-трудовой потенциал человека, второй способствует его реализации, в том числе исходя из таких жизненных целей, как карьера, профессиональная самореализация и материальное благополучие. Как свидетельствуют данные С.В. Мареевой, «среди наиболее распространенных жизненных целей самым сложным для россиян представляется достижение хорошего заработка и престижной работы, в то время как наиболее доступна возможность быть профессиона- 
лом в своей области (считают, что уже добились этого или смогут добиться 86 \%; насколько этот профессионализм действительно такого уровня - отдельный вопрос, но в данном случае для нас важны именно субъективные оценки). Высока и доля тех, кто оптимистично оценивает возможности иметь интересную работу и заниматься любимым делом - они составляют более 70 \% населения» [Мареева, 2019, с. 333].

И данные массового опроса, и результаты интервью свидетельствуют о достаточно высокой значимости роли образования в субъективном осмыслении факторов жизненного успеха. Многие участники интервью заявляли об этом с категоричностью: «Какова, поВашему, роль образования в достижении жизненного успеха? - Высокая. Образование на первом месте (мужчина, 66 лет, поселок, районный центр); «Если человек необразован, он вообще в эти круги [успешных людей] никогда не попадет» (мужчина, 50 лет, село); «Первая, главная, основа, вообще, характера - как учишься, тем и получишься» (женщина, 33 года, город, районный центр).

Некоторые суждения были не столь однозначными. В них образование рассматривалось, скорее, как один из факторов жизненного успеха, и не всегда самый главный: «Нельзя сказать, что без образования нельзя что-то достичь. Можно. Но с образованием людей, которые что-то достигают, процент выше. Образование играет роль, может быть, не ключевую» (мужчина, 53 года, поселок, районный центр); «Ну, образование это фундамент, а вот что потом как получится дальше - это уже от очень многих факторов зависит. Но и без образования совершенно тоже нельзя. Все-таки образование кругозор расширяет, дает основу» (мужчина, 53 года, город, районный центр).

Но встречались и высказывания, негативные по отношению к образованию как фактору жизненного успеха: «Никакой роли нет. Минимальная. Фактически никакой» (женщина, 50 лет, город, районный центр); «В современной России, я считаю, образование утеряло свою прежнюю роль» (женщина, 26 лет, областной центр).

Количественная оценка роли образования в достижении карьерного и материального благополучия, полученная в ходе массового опроса, оказалась относительно невысокой, но и не низкой. По 5-балльной шкале (где 1 - самая малая, 5 - очень большая) оценка роли образования составила 3,58 балла. При этом 14,5 \% опрошенных склонны считать эту связь слабой или скорее слабой, а 53,3 \% - сильной или достаточно сильной (табл. 1).

Таблица 1 Table 1

Распределение ответов на вопрос: «С Вашей точки зрения, какую роль в нынешних российских условиях играет образование в достижении человеком карьерного и материального успеха?», \% Distribution of answers to the question: « From your point of view, what role does education play in the achievement of human career and material success in the current Russian conditions? \%

\begin{tabular}{|c|c|c|}
\hline Значения & Частота & \% от опрошенных \\
\hline $3,0=3,3$ & 388 & 32,3 \\
\hline $3,8=4,1$ & 360 & 30,0 \\
\hline $4,6=5,0$ & 279 & 23,3 \\
\hline $1,8=2,1$ & 123 & 10,3 \\
\hline $1,0=1,3$ & 50 & 4,2 \\
\hline ИТОГО: & 1200 & 100,0 \\
\hline
\end{tabular}

Примечание: среднее (индекс): $3,58 \pm 0,06$ 
Таким образом, лишь половина жителей российской провинции рассматривает институт образования в качестве работающего канала восходящей социальной мобильности, а образование - как прикладной культурный капитал. Но при этом и достаточно заметная часть населения не считает их значимыми для индивидуального жизненного успеха, а относительное большинство опрошенных $(32,2 \%)$ оценило вклад образования достаточно скромно. Характерно, что молодежь 18-29 лет оценивает вклад образования в достижение жизненного успеха скромнее, чем по выборке в целом - в 3,28 балла, что свидетельствует о более аномическом мировоззрении молодого поколения, может быть, в определенной мере - о принятии неопределенности в качестве основополагающего параметра современного общества.

И что важно, еще ниже, хотя и ненамного, оказалась оценка респондентами реальных возможностей получения качественного образования в месте своего проживания. Она составила 3,27 балла по 5-балльной шкале. Низкую и очень низкую оценку при этом дали при этом $21,4 \%$ опрошенных, высокую и достаточно высокую - 42,6 \%. Относительное большинство респондентов (35,9 \%) предпочло остановиться на среднем значении оценочной шкалы. Вполне предсказуемо более высокие оценки возможностям получения качественного образования дают респонденты, проживающие в городах с населением свыше 100 тыс. человек (3,43 балла), нежели те, кто живет в городских поселениях с населением менее 100 тыс. (3,05 балла) или в сельской местности (3,11 балла), хотя эта разница не так уж существенна. Оценка молодежи 18-29 лет (3,25 балла) практически соответствует среднему по выборке значению (табл. 2).

Таблица 2

Table 2

Распределение ответов на вопрос: «Оцените по 5-балльной шкале возможности получения качественного образования в месте Вашего проживания

(1 - самые малые, 5 - очень большие)», абс., \%

Distribution of answers to the question: « Evaluate on a 5-point scale the possibility of obtaining a quality education in your place of residence ( 1 - the smallest, 5 - very large)», abs., \%

\begin{tabular}{|c|c|c|}
\hline Значения & Частота & \% от опрошенных \\
\hline $3,0=3,3$ & 431 & 35,9 \\
\hline $3,8=4,1$ & 370 & 30,8 \\
\hline $1,8=2,1$ & 178 & 14,8 \\
\hline $4,6=5,0$ & 142 & 11,8 \\
\hline $1,0=1,3$ & 79 & 6,6 \\
\hline ИТОГО: & 1200 & 100,0 \\
\hline
\end{tabular}

Примечание: среднее(индекс): $3,27 \pm 0,06$.

Таким образом, даже в таких достаточно благополучных субъектах федерации, как Белгородская и Воронежская области, образовательные институты далеко не всегда могут удовлетворить запрос граждан на качественное образование, вынуждая молодых людей к образовательной миграции - как правило, в Москву и Санкт-Петербург, а иногда - и за пределы России. По результатам всероссийского опроса ВЦИОМ (2019 г., телефонное интервью по стратифицированной двухосновной случайной выборке стационарных и мобильных номеров объемом 1600 респондентов), 30 \% опрошенных россиян хотели бы, чтобы их дети или внуки (как имеющиеся, так и потенциальные) получили образование за 
рубежом, а у 1 \% респондентов дети или внуки уже учатся в других странах [Высшее образование...].

Но даже качественное образование, как отмечалось ранее, не гарантирует реализации жизненных планов, достижения материального и профессионального успеха. Слабая дифференциация большинства региональных экономик, узость рынков труда, низкий уровень зарплат в большинстве отраслей, распространенность непотизма и иных проявлений клановости не способствуют реализации жизненных планов, связанных с карьерой и профессиональным ростом, и оказывают фрустрирующее воздействие на общественное сознание. В особенности это относится к выпускникам высших учебных заведений, которые сразу по выходу сталкиваются с комплексом проблем, прежде всего, трудоустройства по полученной специальности.

Как свидетельствуют данные общероссийских исследований, в общественном мнении россиян «пространство типичных жизненных шансов у жителей российских столиц (Москвы и Санкт-Петербурга) представляется в целом шире, чем у жителей провинций, и проживание в столицах связано с большими возможностями для населения в разных сферах» [Мареева, 2018, с. 369]. По данным нашего исследования, условия провинции далеко не всегда позволяют самореализацию в профессионально-деловой сфере. Так, значительная доля респондентов (42,1 \%) убеждена в том, что без связей, «блата» в их городе, районе невозможно ни хорошее трудоустройство, ни карьерный рост, ни эффективная предпринимательская деятельность и иные способы профессиональной самореализации. Безусловно, это субъективная оценка, но в ее основании лежат не только стереотипы, но и личный опыт либо опыт, транслируемый в привычных кругах коммуникации. И эта оценка зачастую трансформируется в соответствующую установку, оказывающую негативное воздействие на индивидуальную активность либо канализирующую ее в иных направлениях (миграция, уход в приватные практики, саморазрушающее поведение и пр.). Еще 32,3 \% опрошенных отметили наличие в месте их проживания возможностей для трудоустройства, карьерного роста, развития предпринимательства, но с тем условием, что воспользоваться ими могут лишь очень способные и целеустремленные люди. И лишь 15,9 \% респондентов отметили наличие в их городе или районе большого объема возможностей в профессионально-деловой сфере для всех (табл. 3).

Таблица 3

Table 3

Распределение ответов на вопрос: «Как вы думаете, в вашем городе или районе есть все возможности для трудоустройства, карьерного роста, развития предпринимательства и других способов профессиональной самореализации?», \%

Distribution of answers to the question: «Do you think that your city or region has all the opportunities for employment, career growth, entrepreneurship and other ways of professional self-realization?», \%

\begin{tabular}{|l|c|c|}
\hline \multicolumn{1}{|c|}{ Значения } & Частота & $\begin{array}{c}\% \\
\text { от опрошенных }\end{array}$ \\
\hline Да, таких возможностей много; дело лишь в желании & 191 & 15,9 \\
\hline $\begin{array}{l}\text { Такие возможности есть, но воспользоваться ими могут лишь } \\
\text { очень способные и целеустремленные люди }\end{array}$ & 387 & 32,3 \\
\hline $\begin{array}{l}\text { Такие возможности есть только для тех, у кого есть род- } \\
\text { ственные связи, «блат» }\end{array}$ & 505 & 42,1 \\
\hline Затрудняюсь ответить & 117 & 9,7 \\
\hline ИТОГО: & 1200 & 100,0 \\
\hline
\end{tabular}


Поставленные в ходе проведения полуформализованных интервью вопросы о возможности реализации жизненных шансов и достижении жизненного успеха в месте своего проживания выявили преобладание крайне скептических представлений о соответствующих условиях в селах, малых, а зачастую и крупных городах российской провинции. Безусловно, в ходе интервью фиксировались и высказывания респондентов о том, что активный человек сможет найти свою нишу и достичь жизненного успеха даже в глухой провинции: «Как вы считаете, где больше шансов преуспеть, добиться успеха в жизни там, где вы проживаете или где-то в другом месте? - Можно везде абсолютно. Можно... Ну, конечно, в городе больше вариантов. Но можно и здесь. Вообще проще преуспеть там, где больще людей, потому что в основном на людях деньги зарабатывают. Но, в принципе, можно и в деревне взять 100 гектар. И сажай, выращивай, вези в город. Или в город езжай. Можно везде при желании. А если нету желания, то и под носом ничего не будешь видеть, ничего не делать» (мужчина, 31 год, село).

Но в подавляющем большинстве случаев в ответах респондентов просматривалась или было прямо выражена неудовлетворенность социальной ситуацией, состоянием рынка труда и набором условий для самореализации в месте своего проживания. В меньшей степени это касается крупных городов, особенно Воронежа, в гораздо большей - сел и поселков, в том числе, районных центров. При этом часть респондентов, хотя и небольшая, в качестве предпочтительных по объему жизненных шансов территорий указывала другие страны. И, что также следует отметить, негативные оценки жизненным шансам в провинции давали представители абсолютно всех возрастных групп: «Если я захочу чего-то добиться в любом городе, я добьюсь, потому что врачи везде нужны, но в то же время я повторюсь, что в таких городах, как Москва и Питер, если я буду хорошим спечиалистом, то там меня будут ценить больще» (женщина, 18 лет, живет в селе, учится в областном центре); «В нашем случае, в России шансов чего-то достичь - это только крупный город. Москва, конечно, прежде всего. Уровень жизни Москвы и всей остальной России - разный» (мужчина, 53 года, райцентр); «Людям всегда кажется, что трава зеленее у соседей в саду. Успех практически не зависит от местоположения, но если учесть некоторые особенности нашей области (воровство проектов, обязательные условия открытия), возможно, где-то в другом месте. - А где именно? В другом населенном пункте вамего региона, в другом регионе России или за ее пределами? - За пределами России» (женщина, 22 года, областной центр); «У нас не все находят работу, которая нравится. Лучше уезжать куда-то. У нас нет работь» (женщина, 60 лет, село); «Я думаю, перспектива в нашем городе только одна - это все, что непосредственно связано с сельским хозяйством. Мне хотелось бы, чтобы это был другой совсем даже регион. Может быть, даже за пределами России. Я, конечно, была бы безумно счастлива, если бы дети реализовали себя где-то в другой стране» (женщина, 39 лет, райцентр).

Таким образом, российская провинция предоставляет жизненные шансы, прежде всего, тем, кто способен ими воспользоваться - наиболее активным и амбициозным людям, а также обладателям значительного по объему социального капитала, связанного в основном с семейными ресурсами и связями. В пространственном отношении жизненные шансы распределяются неравномерно - их объем в субъективных оценках жителей достаточно сильно варьирует от сел до областных центров. Но даже в последних жизненные шансы несопоставимы с возможностями мегаполисов или стран Западной Европы, Северной Америки и Китая. И, главное, в огромном количестве случаев жизненные шансы российской провинции сводятся к возможности старта в те самые мегаполисы России или за ее пределы.

\section{Заключение}

Рассматривая жизненные шансы как вероятность достижения жизненного успеха, определяемую совокупностью внешних условий (социальных, институциональных, ин- 
фраструктурных) и силы внутренней мотивации индивида или группы, следует отметить их пространственную детерминацию. Дифференциация географического, социального и культурного пространства России на «центр» и «провинцию» имеет давнюю традицию, связанную с тем, что «центр», столица выступали триггером экономического, политического и культурного развития периферии. Эта неравномерность сохраняется до настоящего времени и выражается, в том числе, в объективном и субъективном неравенстве возможностей достижения жизненных целей и успеха. Неравенство жизненных шансов достаточно остро осознается жителями российской провинции как применительно к экономическим и культурным центрам - Москве и Санкт-Петербургу, так и внутри провинциального социума - между селами и малыми городами, с одной стороны, и областными центрами, с другой.

Однако все же провинциальные социумы предстают более гомогенными по объему жизненных шансов, точнее, по барьерам и ограничениям их реализации. Узость рынков труда, низкий уровень зарплат в большинстве отраслей региональных экономик, зачастую засилье непотизма и иных проявлений клановости консервируют традиционалистские ценности большей части жителей российской провинции и в то же время формируют неудовлетворенность социальной ситуацией и выталкивают наиболее амбициозных людей за пределы провинциальных социумов. Применительно к молодежи - это еще и неудовлетворенность условиями для получения качественного образования, особенно в малых городах и сельской местности. Тем самым российское общество продолжает воспроизводить модель дифференцированного пространственного развития, а провинция остается преимущественно источником ресурсов (трудовых, интеллектуальных и пр.) для ограниченного количества точек роста и инноваций в стране.

\section{Список источников}

Высшее образование с иностранным акцентом. URL: https://wciom.ru/index.php?id =236\&uid=9930 (дата обращения 02.10.2019).

\section{Список литературы}

1. Аникин В.А. 2018. Социальная стратификация по жизненным шансам: попытка операционализации для массовых опросов. Мониторинг общественного мнения: Экономические и социальные перемены, 4: 39-67.

2. Бауман 3. 2008. Текучая современность/ пер. с англ. под ред. Ю.В. Асочкова. Спб., Питер, 240 c. $147-156$.

3. Вебер М. 1994. Основные понятия стратификации. Социологические исследования, 5:

4. Дарендорф Р. 2002. Современный социальный конфликт. Очерк политики свободы. М., РОССПЭН, $284 \mathrm{c.}$

5. Звоновский В.Б. 2003. Российская провинция: массовое сознание и социальные институты. Общественные науки и современность, 1: 78-89.

6. Злотникова Т.С., Ерохина Т.И., Летина Н.Н., Киященко Л.П. 2014. Русская провинция в философском дискурсе: концептуализация метафоры. Вопросы философии, 11: 126-136.

7. Ильин В.И. 2019. Старый русский Север как пространство жизненных шансов: история и современность. Журнал Фронтирных исследований, S4.2 (16): 310-330.

8. Каравай А.В. 2019. Основные модели социально-экономической адаптации в разных стратах российского общества. TERRA ECONOMICUS, 3: 128-145.

9. Кордонский С.Г., Плюснин Ю.М., Крашенинникова Ю.А., Тукаева А.Р., Моргунова О.М., Ахунов Д.Э., Бойков Д.В. 2011. Российская провинция и ее обитатели (опыт наблюдения и попытка описания). Мир России, 1: 3-33.

10. Кузьмина Е.И. 2013. Социальные неравенства и жизненные выборы молодежи. Вестник МГМО Университета, 6: 230-232. 
11. Лапин Н.И. 2010. Новые проблемы исследований региональных сообществ. Социологические исследования, 7: 28-37.

12. Мареева С.В. 2018. Жизненные шансы жителей столиц и провинций в массовом сознании. Мониторинг общественного мнения: Экономические и социальные перемены, 6: 365385.

13. Мареева С.В. 2019. Неравенство жизненных шансов россиян в сфере баланса жизни и труда. Мониторинг общественного мнения: Экономические и социальные перемены, 3: 324-344.

14. Пинская М.А., Косарецкий С.Г., Груничева И.Г. 2014. Жизненные шансы для всех учеников. Образовательная панорама, 1: 10-16.

15. Реутов Е.В., Реутова М.Н. 2019. Ментальность жителей российской провинции: устремленность в будущее и способы его достижения. Научные ведомости Белгородского государственного университета: Философия. Социология. Право, 3: 410-418.

16. Реутов Е.В., Реутова М.Н., Шавырина И.В. 2019. Реципрокность в сетях взаимопомощи (на материалах регионального исследования). Социологические исследования, 3 : 106-117.

17. Чередниченко Г.А. 2005. Личные планы выпускников средней школы. Социологические исследования, 7: 114-117.

18. Breen, R. 2005. Foundations of a neo-Weberian class analysis. In E. Wright (Ed.). Approaches to Class Analysis. Cambridge: Cambridge University Press: 31-50.

19. Dahrendorf R. 1979. Life chances. Approaches to social and political theory. Chicago: University of Chicago Press, $181 \mathrm{p}$.

20. Giddens A. 1973. The Class Structure of the Advanced Societies. London: Hutchinson, 336 p.

\section{References}

1. Anikin V.A. 2018. Social'naya stratifikaciya po zhiznennym shansam: popytka operacionalizacii dlya massovyh oprosov [Social stratification based on life chances: operationalization for mass surveys]. Monitoring obshchestvennogo mneniya: Ekonomicheskie i social'nye peremeny, 4: 39-67.

2. Bauman Z. 2008. Tekuchaya sovremennost' [Liquid Times]. SPb.: Piter, 240 p.

3. Weber M. 1994. Osnovnye ponyatiya stratifikacii [Basic concepts of stratification]. Sociologicheskie issledovaniya, 5: 147-156.

4. Dahrendorf R. 2002. Sovremennyj social'nyj konflikt. Ocherk politiki svobody [Der moderne soziale Konflikt. Essay zur Politik der Freiheit]. Moscow: POSSPAN, 284 p.

5. Zvonovskij V.B. 2003. Rossijskaya provinciya: massovoe soznanie i social'nye instituty [Russian province: mass consciousness and social institutions]. Obshchestvennye nauki i sovremennost', 1: 78-89.

6. Zlotnikova T.S., Erohina T.I., Letina N.N., Kiyashchenko L.P. 2014. Russkaya provinciya v filosofskom diskurse: konceptualizaciya metafory. [Russian province in philosophical discourse: conceptualization of metaphor]. Voprosy filosofii, 11: 126-136.

7. Il'in V.I. 2019. Staryj russkij Sever kak prostranstvo zhiznennyh shansov: istoriya i sovremennost' [The old russian north as a space of life chances: history and contemporary period]. Zhurnal Frontirnyh issledovanij, S4.2 (16): 310-330.

8. Karavaj A.V. 2019. Osnovnye modeli social'no-ekonomicheskoj adaptacii v raznyh stratah rossijskogo obshchestva [Basic models of socio-economic adaptation in different strata of Russian society]. Terra economicus, 3: 128-145.

9. Kordonskij S.G., Plyusnin Yu.M., Krasheninnikova Yu.A., Tukaeva A.R., Morgunova O.M., Ahunov D.E., Bojkov D.V. 2011. Rossijskaya provinciya i ee obitateli (opyt nablyudeniya i popytka opisaniya). [Russian province and its inhabitants (observation experience and attempt to describe)]. Mir Rossii, 1: 3-33.

10. Kuz'mina E.I. 2013. Social'nye neravenstva i zhiznennye vybory molodezhi [The youth in Russia: inequalities and living choices]. Vestnik MGMO Universiteta, 6: 230-232.

11. Lapin N.I. 2010. Novye problemy issledovanij regional'nyh soobshchestv. [New problems in the study of regional communities]. Sociologicheskie issledovaniya, 7: 28-37. 
12. Mareeva S.V. 2018. Zhiznennye shansy zhitelej stolic i provincij v massovom soznanii. [Life chances of population in capitals and provinces in mass consciousness]. Monitoring obshchestvennogo mneniya: Ekonomicheskie i social'nye peremeny, 6: 365-385.

13. Mareeva S.V. 2019. Neravenstvo zhiznennyh shansov rossiyan v sfere balansa zhizni i truda [Inequality of life chances in worklife balance of Russians]. Monitoring obshchestvennogo mneniya: Ekonomicheskie i social'nye peremeny, 3: 324-344.

14. Pinskaya M.A., Kosareckij S.G., Grunicheva I.G. 2014. Zhiznennye shansy dlya vsekh uchenikov [Vital Opportunities for All Pupils]. Obrazovatel'naya panorama, 1: 10-16.

15. Reutov E.V., Reutova M.N. 2019. Mentality of the residents of the Russian province: aspiration for the future and methods of its achievement. Belgorod State University Scientific bulletin. Issues Philosophy. Sociology. Law. 3: 410-418. (In Russian)

16. Reutov E.V., Reutova M.N., Shavyrina I.V. 2019. Reciproknost' v setyah vzaimopomoshchi (na materialah regional'nogo issledovaniya). [Reciprocity in mutual aid networks (on the data of a regional study)]. Sociologicheskie issledovaniya, 3: 106-117.

17. Cherednichenko G.A. 2005. Lichnye plany vypusknikov srednej shkoly. [Personal high school graduate plans]. Sociologicheskie issledovaniya, 7: 114-117.

18. Breen, R. 2005. Foundations of a neo-Weberian class analysis. In E. Wright (Ed.), Approaches to Class Analysis. Cambridge: Cambridge University Press: 31-50.

19. Dahrendorf R. 1979. Life chances. Approaches to social and political theory. Chicago: University of Chicago Press, $181 \mathrm{p}$.

20. Giddens A. 1973 The Class Structure of the Advanced Societies. London: Hutchinson, 336 p.

\section{ИНФОРМАЦИЯ ОБ АВТОРАХ}

Реутов Евгений Викторович, доцент кафедры социальных технологий и государственной службы института экономики и управления Белгородского государственного национального исследовательского университета, г. Белгород, Россия

Реутова Марина Николаевна, доцент кафедры социальных технологий и государственной службы института экономики и управления Белгородского государственного национального исследовательского университета, г. Белгород, Россия

\section{INFORMATION ABOUT THE AUTHORS}

Evgenij V. Reutov, associate professor of the Department of social technologies and public administration, Institute of economics and management, Belgorod National Research University, Belgorod, Russia

Marina N. Reutova, associate professor of the Department of social technologies and public administration, Institute of economics and management, Belgorod National Research University, Belgorod, Russia 